\title{
CLIMATE CHANGE AND BANK STABILITY: THE MODERATING ROLE OF GREEN FINANCING AND RENEWABLE ENERGY CONSUMPTION IN ASEAN
}

\author{
${ }^{1}$ Hafiz Waqas Kamran, Assistant Professor, Faculty of Business Administration, Iqra \\ University, Karachi, Pakistan, Email: hafiz.waqas@iqra.edu.pk \\ ${ }^{2}$ Muhammad Haseeb, Senior Lecturer, Faculty of Business \& Law, Taylor's University, \\ Malaysia: Email: muhammad.haseeb@taylors.edu.my \\ ${ }^{3}$ Van Chien Nguyen, Thu Dau Mot University, Vietnam. Email: chiennv@tdmu.edu.vn
}

${ }^{4}$ Thu Thuy Nguyen, Academy of Finance, Vietnam. Email: nguyenthuthuy@ hvtc.edu.vn

\begin{abstract}
The present investigation empirically determines the comparative as well as combine panel estimations for the relationship between climate change and bank stability in three selected ASEAN countries; Malaysia, Indonesia and Thailand with the moderation of green financing and renewable energy. Five leading banks were chosen from each country based on green financing usage. The dependent variable was bank stability, which was proxies by z-score of ROA and ROE along with SDROA and SDROE. Climate change was the main independent variable, which was proxies by $\mathrm{CO} 2$ emission while the control variable was organization quality. Panel data estimation was applied using a fixed effect, random effect and pooled OLS technique along with the Hausman test and LM test. Both Hausman and LM tests were not significant which conformed pooled data estimation as the appropriate modelling. The comparative findings indicate that bank stability strongly decreased by climate change in Malaysia, Indonesia and Thailand. The Green financing strongly enhances bank stability in the case of Malaysia and Thailand while renewable energy is a less important factor to enhance the bank stability for all the three countries. The moderation effect of green financing significantly enhances bank stability in the case of Malaysia and Thailand while the moderation effect of renewable energy enhances bank stability in the case of Malaysia and Indonesia only. The combined estimates conclude that climate changes strongly decreases the bank stability in the ASEAN region while the green financing and renewable energy positively influences the bank stability in this region with low significance. The moderation effect of green financing, as well as renewable energy positively, enhances the bank stability measures of ZROA and ZROE only in this region. The policy implication for this empirical investigation concludes that the policymakers in ASEAN region should promote green financing in all the banks with renewable energy in their economies as the source of alternative energy consumption to control to devastating changes in climate so that bank stability in this region is insured.
\end{abstract}

Keywords: Bank Stability, climate change, Green financing, renewable energy, banking sector, panel data analysis, ASEAN region.

\section{Introduction}

The ever-changing climate has become a challenge for modern economies not only in terms of their survival on earth but also their economic stability and financial stability. According to the world bank, the changes in climate is supposed to hit the largest and most developed nations of the world. The climate change may include the rising level of temperature, increasing level of the sea and frequent disastrous changes in weather conditions including earth quacks, floods, etc. These changes have created risk in terms of shortage of food, drinking water supplies, increasing level of diseases, hunger, poverty, etc. The changes in a climate not only impact the life of a common man in developing countries but also impact the different organizations at large. Today, most of the organizations are

ISSN 1869-0459 (print)/ISSN 1869-2885 (online)

(c) 2020 International Research Association for Talent Development and Excellence

http://www.iratde.com 
promoting green financing in their projects to enhance the usage of environment-friendly projects so as to decrease the negative impact of climate on their economy. In addition, most of the countries are going towards using alternative sources of energy in the form of renewable energy consumption so as to decrease the pollution level in their environment to decrease the negative impact of climate in their economies.

The present research aimed to investigate the impact of climate change on bank stability in Malaysia, Indonesia and Thailand with a moderating effect of green financing and renewable energy. The specific research objective of the study is as follows:

- To examine the impact of climate change on bank stability for comparative panels of Malaysia, Indonesia and Thailand banks during 2012-2018 data frequency.

- To investigate the interaction of green financing as the moderator between climate change and bank stability for the comparative panels of Malaysia, Indonesia and Thailand banks during 2012-2018 data frequency.

- To explore the interaction of renewable energy consumption as the moderator between climate change and bank stability for the comparative panels of Malaysia, Indonesia and Thailand banks during 2012-18 data frequency.

- To determine the combined panel's estimates of the above.

- To infer the comparative and combined panel policy implications of the study.

In order to accomplish the study objectives as stated above, the following research questions need to be explored in order to analyze the study.

- How bank stability is influenced by the changes in climate for comparative panels of Malaysia, Indonesia and Thailand for an annual stream of 2012-2018?

- Does the green financing moderate the relationship between bank stability and climate change for comparative panels of Malaysia, Indonesia and Thailand during 2012-2018?

- How does renewable energy consumption moderate the relationship between bank stability and climate change for the comparative panels of Malaysia, Indonesia and Thailand considering 2012-2018 data?

- What are the combined panel's estimates for the above?

- What policy implications are inferred from this study based on comparative and combined panel estimates?

\section{Literature Review}

The past literature includes a very limited number of studies showing the relationship between climate change and commercial bank stability. A large number of historical evidences revealed the determining factors of bank stability. De Jonghe (2010) discussed that banking stability is mainly enhanced by the overall economic condition like stock market stability. He considered market index as the determining factors of overall commercial bank stability. Soedarmono, Machrouh, and Tarazi (2011) found that economic environment affects the stable bank condition adversely. Jahn and Kick (2012) considered the role of indicators of early warnings, effects from regional spillovers and business cycle as the determining factors of instable conditions of banks. Shahid and Abbas (2012) considered firm specific, economy specific and governance specific factors in relation to stability of bank. They found that organizational quality in terms of governance negatively impact the bank stability. R.-I. Diaconu and Oanea (2014) concluded their research with the findings that interbank offered rate and growth rate of GDP are mainly responsible factors that strongly affect the stability of commercial banks. Fang, Hasan, and Marton (2014) considered that environment of an institution plays a strong role for bank stability in addition to domestic nature of the bank. I.-R.

ISSN 1869-0459 (print)/ISSN 1869-2885 (online) (c) 2020 International Research Association for Talent Development and Excellence http://www.iratde.com 
Diaconu and Oanea (2015) found that institutional factors like loan as proportion of assets, deposit ratio, salary expense ratio, equity to assets ratio and macro-economic factors like GDP growth rate strongly affect the banking system stability. Karim, Al-Habshi, and Abduh (2016) conducted a time-series analysis for determining the relationship between macro-economic factors that determine the commercial bank stability could not found the longrun relationship between the dependent and independent variable in their study. Sinha and Sharma (2016) considered a study with the panel data in determining the banking system stability and responsible factors using dynamic panel data estimation technique also considered firm specific factors for this purpose but they did 'not used macroeconomic indicators for this purpose. Ibrahim and Rizvi (2017) concluded that size of the bank matters significantly in enhancing the stability of bank. They found that large banks are more stable than small banks. Danişman (2018) concluded that the bank stability is only determined by bank specific institutional factors and not significant with macroeconomic factors. Ozili (2018) found negative relationship between organizational quality and bank stability with highly significant coefficient. Many past studies either found bank specific factors that determine the bank stability or the economic factors like GDP growth, inflation, organizational quality, etc., like the studies conducted by (Ahamed \& Mallick, 2019; Albaity, Mallek, \& Noman, 2019; Ashraf, Rizwan, \& L'Huillier, 2016; Gudmundsson, NgokaKisinguh, \& Odongo, 2013; Guy \& Lowe, 2011; Hsieh, Chen, Lee, \& Yang, 2013; Kamran, Mohamed-Arshad, \& Omran, 2019; Koetter \& Poghosyan, 2010; Mat Rahim \& Zakaria, 2013; Moyo, Nandwa, Council, Oduor, \& Simpasa, 2014; Rupeika-Apoga, Zaidi, Thalassinos, \& Thalassinos, 2018; Tan \& Anchor, 2016; Umar \& Sun, 2018; Vallascas \& Keasey, 2012).

After Analyzing the past literature, it is evident that none of the previous studies explored the relationship between commercial bank stability on the basis of climate change affect. Furthermore, the factor like green financing and renewable energy could not be found as the moderating factor coupled with climate change as the determining factor of commercial bank's stability. So the present empirical research study determines that aforesaid research gap through systematic estimation of comparative as well as combined panels of selected ASEAN region countries.

\section{Data and Methodology}

The ultimate drive for this study is to empirically determine the climate change impact on bank stability for Malaysia, Indonesia and Thailand in comparative panel, as well as combined panel, approach considering the role of green financing as well as renewable energy as the moderating factors. For this purpose, five banks each were selected on the basis of green financing from each of the three selected countries. The bank stability as the dependent variable of the study was measured by four proxies; $\mathrm{Z}$ score of ROA, ROE and SD of ROA and ROE. The independent variable was climate change which was measured by $\mathrm{CO} 2$ emissions. The independent variables were green financing, renewable energy and organizational quality while the green financing and renewable energy consumption were also used as the moderating variables of this empirical research investigation. The data for this purpose was collected from the financial statement of the respective banks as well as from the WDI database along with WDI governance index databases from the year 2012-2018. The detail measures and sources of data were given in table 1.

Table 1: Variable Description and Sources

\begin{tabular}{|c|c|c|c|}
\hline Symbols & Full Name & Proxies and Measurements & Sources of Data \\
\hline $\mathrm{BS}$ & Bank Stability & $\begin{array}{ll}\text { - } & \mathrm{ZROE}=(\mathrm{ROE}+\mathrm{EQA}) / \mathrm{SDROE} \\
\text { - } & \mathrm{ZROA}=(\mathrm{ROA}+\mathrm{EQA}) / \mathrm{SDROA} \\
\text { - } & \mathrm{SDROA} \\
\text { - } & \mathrm{SDROE}\end{array}$ & $\begin{array}{c}\text { Financial Statements of } \\
\text { Relevant Banks }\end{array}$ \\
\hline $\mathrm{CC}$ & Climate Change & CO2 emissions (metric tons per capita). & WDI \\
\hline GF & Green Financing & $\begin{array}{c}\text { Dummy Variable } \\
\text { Bank using Green Financing in a particular } \\
\text { year }=1\end{array}$ & $\begin{array}{c}\text { Financial Statements of } \\
\text { Relevant Banks }\end{array}$ \\
\hline
\end{tabular}

ISSN 1869-0459 (print)/ISSN 1869-2885 (online)

(c) 2020 International Research Association for Talent Development and Excellence

http://www.iratde.com 
Talent Development \& Excellence

Vol.12, No.2s, 2020, 3738-3751

The bank not using green financing in a particular year $=0$

\begin{tabular}{cccc}
\hline REC & $\begin{array}{c}\text { Renewable } \\
\text { Energy } \\
\text { Consumption }\end{array}$ & $\begin{array}{c}\text { Renewable energy consumption (\% of total } \\
\text { final energy consumption) }\end{array}$ & WDI \\
\hline OG & $\begin{array}{c}\text { Organizational } \\
\text { Quality }\end{array}$ & $\begin{array}{c}\text { Sum of Control of Corruption, Governance } \\
\text { effectiveness, Political stability, Regulatory } \\
\text { quality, rule of law and Voice \& } \\
\text { accountability values }\end{array}$ & WDI Governance Index \\
\hline GFCC & First Moderation & Green Financing $\times$ Climate Change & $\begin{array}{c}\text { Product of computed values } \\
\text { from financial statements and } \\
\text { WDI data }\end{array}$ \\
\hline RECCC & Second & Renewable Energy Consumption $\times$ Climate \\
& Moderation & Change & $\begin{array}{c}\text { Product of computed values } \\
\text { from financial statements and } \\
\text { WDI data }\end{array}$ \\
\hline
\end{tabular}

\section{Modelling of the study}

The present research empirically investigates the purpose of this examination using comparative as well as combined panel estimates. For this purpose, fixed effect, random effect and pooled data models were estimated along with Hausman specification and LM tests. For executing the present empirical research investigation as per the requirements of the study, the following equation 1 is derived as the basic panel data econometric model without the moderation effect.

$$
\begin{aligned}
(\text { Bank Stablity })_{i t}= & \beta_{0}+\beta_{1}(\text { Climate Change })_{i t}+\beta_{2} \quad(\text { Green Financing })_{i t}+\beta_{3}(\text { Renewable Energy })_{i t}+ \\
& \beta_{4}(\text { Organizational Quality })_{i t}+\varepsilon_{i t}
\end{aligned}
$$

To control the skewness of data, equation 1 is transformed into equation 2 by adding natural-log-term with each variable in the model excluding the moderation effect of green financing and renewable energy consumption in the model.

$\begin{array}{ccccc}\text { Ln }(\text { Bank Stablity })_{i t}= & \beta_{0}+ & +\quad \beta_{1} \operatorname{Ln}(\text { Climate Change })_{i t}+ & \beta_{2} & \text { Ln }(\text { Green Financing })_{i t}+ \\ +\beta_{3} \operatorname{Ln}(\text { Renewable Energy })_{i t}+\beta_{4} \operatorname{Ln}(\text { Organizational Quality })_{i t}+\varepsilon_{i t} & (2)\end{array}$

To consider fixed effect in the basic regression model, the following equation 2.1 is formed as the fixed effect estimation equation excluding the moderation effect of green financing and renewable energy consumption in the model:

$$
\begin{aligned}
& \text { Ln(Bank Stablity } \left.)_{i t}=a_{i}+\beta_{1} \operatorname{Ln}(\text { Climate Change })_{i t}+\beta_{2} \quad \text { Ln (Green Financing }\right)_{i t}+ \\
& +\beta_{3} \operatorname{Ln}(\text { Renewable Energy })_{i t}+\beta_{4} \operatorname{Ln}(\text { Organizational Quality })_{i t}+\mu_{i t}
\end{aligned}
$$

To consider random effect in the basic regression model, the following equation 2.2 is formed as the random effect estimation equation excluding the moderation effect of green financing and renewable energy consumption in the model:

$\operatorname{Ln}(\text { Bank Stablity })_{i t}=\beta_{0}+\beta_{1} \operatorname{Ln}(\text { Climate Change })_{i t}+\beta_{2} \quad$ Ln (Green Financing $)_{i t}{ }^{+}$ $+\beta_{3} \operatorname{Ln}(\text { Renewable Energy })_{i t}+\beta_{4} \operatorname{Ln}(\text { Organizational Quality })_{i t}+\left(a_{i}+\mu_{i t}\right)(2.2)$

ISSN 1869-0459 (print)/ISSN 1869-2885 (online) (c) 2020 International Research Association for Talent Development and Excellence http://www.iratde.com 
To consider the first moderation effect using green financing in the basic panel data model, the following equation 3 is formed:

Ln (Bank Stablity $)_{i t}=\beta_{0}+\beta_{1} \operatorname{Ln}(\text { Climate Change } \times \text { Green Financing })_{i t}+\beta_{2} \operatorname{Ln}(\text { Renewable Energy })_{i t}+$ $\beta_{3} \operatorname{Ln}(\text { Organizational Quality) })_{i t}+\varepsilon_{i t}$

In order to estimate the first moderation effect of green financing using fixed-effect regression, the following equation 3.1 is formed:

Ln(Bank Stablity $)_{i t}=a_{i}+\beta_{1} \operatorname{Ln}(\text { Climate Change } \times \text { Green Financing })_{i t}+\beta_{2}$ Ln $(\text { Renewable Energy })_{i t}+$

$$
\beta_{3} \operatorname{Ln}(\text { Organizational Quality) })_{i t}+\mu_{i t}
$$

In order to estimate the first moderation effect of green financing using random effect regression, the following equation 3.2 is formed:

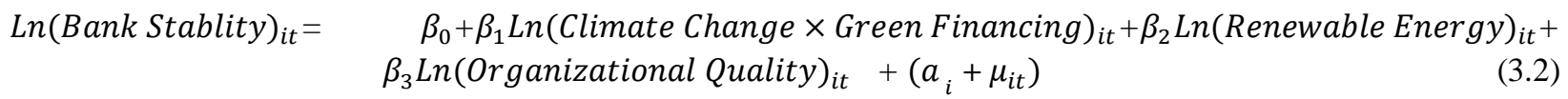

To consider the $2^{\text {nd }}$ moderation effect using renewable energy consumption in basic panel data model, the following equation 4 is formed:

$\operatorname{Ln}(\text { Bank Stablity })_{i t}=\quad \beta_{0}+\beta_{1} \operatorname{Ln}(\text { Climate Change } \times \text { Renewable Energy })_{i t}+\beta_{2}$ Ln $(\text { Green Financing })_{i t}+$ $\beta_{3} \operatorname{Ln}(\text { Organizational Quality })_{i t}+\varepsilon_{i t}$

In order to estimate the 2 nd moderation effect of renewable energy consumption using fixed-effect regression, the following equation 4.1 is formed:

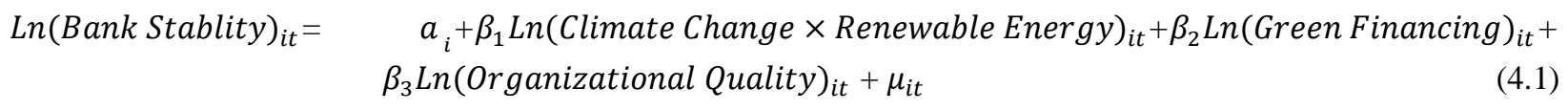

In order to estimate the 2 nd moderation effect of renewable energy consumption using random effect regression, the following equation 4.2 is formed:

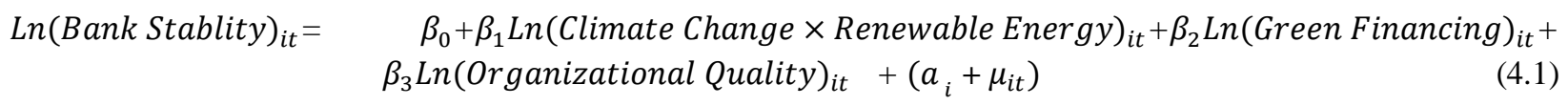

The following equation 5 is formed to estimate the combined moderation effect of green financing as well as renewable energy consumption using basic panel data approach:

Ln $(\text { Bank Stablity })_{i t}=\quad \beta_{0}+\beta_{1} \operatorname{Ln}(\text { Climate Change } \times \text { Green Financing })_{i t}+\beta_{2}$ Ln $($ Climate Change $\times$ Renewable Energy $)_{i t}+\beta_{3} \operatorname{Ln}(\text { Organizational Quality })_{i t}+\varepsilon_{i t}$

The following equation 5.1 is formed to estimate the combined moderation effect of green financing as well as renewable energy consumption using fixed effect panel data approach:

$\operatorname{Ln}(\text { Bank Stablity })_{i t}=\quad a_{i}+\beta_{1} \operatorname{Ln}(\text { Climate Change } \times \text { Green Financing })_{i t}+\beta_{2}$ Ln $($ Climate Change $\times$ Renewable Energy $)_{i t}+\beta_{3} \operatorname{Ln}(\text { Organizational Quality })_{i t}+\mu_{i t}$

The following equation 5.2 is formed to estimate the combined moderation effect of green financing as well as renewable energy consumption using random effect panel data approach:

Ln $(\text { Bank Stablity })_{i t}=\quad \beta_{0}+\beta_{1}$ Ln (Climate Change $\times$ Green Financing $)_{i t}+\beta_{2}$ Ln $($ Climate Change $\times$ Renewable Energy $)_{i t}+\beta_{3} \operatorname{Ln}(\text { Organizational Quality })_{i t}+\left(a_{i}+\mu_{i t}\right)$

ISSN 1869-0459 (print)/ISSN 1869-2885 (online) (c) 2020 International Research Association for Talent Development and Excellence http://www.iratde.com 
Talent Development \& Excellence

Vol.12, No.2s, 2020, 3738-3751

\section{Data Analysis}

The primary motive behind the analysis of present empirical research study is to determine the comparative as well as combined panel estimation for the relationship between climate change and commercial bank stability in selected countries in ASEAN region for the period 2012-18. For this purpose, panel data estimation methods were applied like fixed effect, random effect and pooled OLS methods of estimation including Hausman specification test and LM test to decide between most appropriate approach for estimation purpose. In addition, descriptive statistics and correlation analysis of the variables of the study were also analyzed. The specific detail of analysis is presented under the separate head for each purpose. 
Talent Development \& Excellence

Vol.12, No.2s, 2020, 3738-3751

Table 2: Descriptive Statistics:

\begin{tabular}{|c|c|c|c|c|c|c|c|c|c|c|c|c|c|c|c|c|}
\hline \multirow{2}{*}{$\begin{array}{l}\text { Variables } \\
\end{array}$} & \multicolumn{4}{|c|}{ Malaysia } & \multicolumn{4}{|c|}{ Indonesia } & \multicolumn{4}{|c|}{ Thailand } & \multicolumn{4}{|c|}{ Combined } \\
\hline & Mean & S.D & Min & Max & Mean & S.D & Min & Max & Mean & S.D & Min & Max & Mean & S.D & Min & $\operatorname{Max}$ \\
\hline ZROA & 2.80 & 1.22 & 1.03 & 4.89 & 3.29 & 1.48 & 1.10 & 5.68 & 3.44 & 1.44 & 1.07 & 5.92 & 3.18 & 1.40 & 1.03 & 5.92 \\
\hline ZROE & 3.40 & 1.53 & 1.15 & 5.93 & 3.59 & 1.50 & 1.18 & 5.94 & 3.36 & 1.53 & 1.10 & 5.97 & 3.45 & 1.51 & 1.10 & 5.97 \\
\hline SDROA & 0.52 & 0.29 & 0.00 & 0.98 & 0.45 & 0.30 & 0.01 & 1.00 & 0.49 & 0.30 & 0.02 & 0.98 & 0.49 & 0.30 & 0.00 & 1.00 \\
\hline SDROE & 0.51 & 0.27 & 0.03 & 0.99 & 0.54 & 0.27 & 0.05 & 1.00 & 0.55 & 0.26 & 0.15 & 0.99 & 0.53 & 0.27 & 0.03 & 1.00 \\
\hline $\mathrm{CC}$ & 7.68 & 0.31 & 7.17 & 8.13 & 2.03 & 0.32 & 1.77 & 2.56 & 4.22 & 0.26 & 3.79 & 4.62 & 4.64 & 2.36 & 1.77 & 8.13 \\
\hline GF & 0.49 & 0.51 & 0.00 & 1.00 & 0.54 & 0.51 & 0.00 & 1.00 & 0.49 & 0.51 & 0.00 & 1.00 & 0.50 & 0.50 & 0.00 & 1.00 \\
\hline RE & 4.43 & 0.42 & 3.82 & 5.19 & 37.95 & 0.62 & 36.88 & 38.97 & 23.04 & 0.48 & 22.65 & 24.10 & 21.80 & 13.79 & 3.82 & 38.97 \\
\hline OQ & 2.22 & 0.45 & 1.67 & 2.86 & 0.26 & 0.16 & -0.01 & 0.50 & 1.03 & 0.38 & 0.61 & 1.58 & 1.17 & 0.88 & -0.01 & 2.86 \\
\hline Banks & 5 & 5 & 5 & 5 & 5 & 5 & 5 & 5 & 5 & 5 & 5 & 5 & 15 & 15 & 15 & 15 \\
\hline Years & 7 & 7 & 7 & 7 & 7 & 7 & 7 & 7 & 7 & 7 & 7 & 7 & 7 & 7 & 7 & 7 \\
\hline Observations & 35 & 35 & 35 & 35 & 35 & 35 & 35 & 35 & 35 & 35 & 35 & 35 & 105 & 105 & 105 & 105 \\
\hline
\end{tabular}

Table 2 indicates the summarized results of the data used in the current empirical investigation in the form of mean, standard deviation, minimum and maximum values of the variables used in the study in the country-wise comparative mode as well as in the combined mode of analysis. The Z-score as indicated by ROA shows that the average values as 2.80, 3.29, 3.44 and 3.18 for Malaysia, Indonesia, Thailand as well as in combined panel respectively. The Z-score as indicated by ROE shows that the average values are 3.40, 3.59, 3.36 and 3.45 for these countries and for combined panel respectively. On the other hand, the SDROA shows the average values as $0.52,0.45,0.49$ and 0.49 respectively for the same set of comparative and combined panels respectively. Finally, SDROE shows the average values as $0.51,0.54,0.55,0.53$ for the same set of comparative as well as combined panels respectively. The Climate changes show the highest average value for Malaysia as 7.68 as compared to Indonesia where the average climate change value was recorded the least one as 2.03 and in case of Indonesia, it is 4.22 including 4.64 for the combined average value for the same variable. The green financing average value shows approximately 0.50 on average for each country as well in the combined analysis. The renewable energy shows the lowest average for Malaysia as 4.43 while the highest average value was reported for Indonesia as 37.95 and the $2^{\text {nd }}$ highest average value was reported as 23.04 for Thailand. The average combined value for the same is 21.80 for all the countries selected.

Table 3: Correlation Matrix (Combined)

\begin{tabular}{|c|c|c|c|c|c|c|c|c|c|c|}
\hline & ZROA & ZROE & SDROA & SDROE & $\mathrm{CC}$ & GF & REC & $\mathbf{O Q}$ & $\mathbf{C C} \times \mathbf{G F}$ & $\mathrm{CC} \times \mathrm{REC}$ \\
\hline ZROA & 1.000 & & & & & & & & & \\
\hline ZROE & -0.045 & 1.000 & & & & & & & & \\
\hline & $(0.645)$ & & & & & & & & & \\
\hline SDROA & $\begin{array}{c}0.083 \\
(0.403)\end{array}$ & $\begin{array}{c}-0.115 \\
(0.244)\end{array}$ & 1.000 & & & & & & & \\
\hline SDROE & $\begin{array}{c}0.058 \\
(0.558)\end{array}$ & $\begin{array}{c}0.109 \\
(0.269)\end{array}$ & $\begin{array}{c}0.025 \\
(0.801)\end{array}$ & 1.000 & & & & & & \\
\hline
\end{tabular}

ISSN 1869-0459 (print)/ISSN 1869-2885 (online)

(C) 2020 International Research Association for Talent Development and Excellence http://www.iratde.com 
Talent Development \& Excellence

Vol.12, No.2s, 2020, 3738-3751

\begin{tabular}{|c|c|c|c|c|c|c|c|c|c|c|}
\hline $\mathrm{CC}$ & $\begin{array}{l}-0.112 \\
(0.026)\end{array}$ & $\begin{array}{c}-0.016 \\
(0.071)\end{array}$ & $\begin{array}{r}-0.043 \\
(0.066)\end{array}$ & $\begin{array}{c}-0.027 \\
(0.082)\end{array}$ & 1.000 & & & & & \\
\hline \multirow[t]{2}{*}{ GF } & 0.083 & 0.129 & 0.109 & 0.024 & -0.043 & 1.000 & & & & \\
\hline & $(0.403)$ & $(0.189)$ & $(0.271)$ & $(0.808)$ & $(0.667)$ & & & & & \\
\hline \multirow[t]{2}{*}{ REC } & 0.161 & 0.056 & 0.042 & 0.067 & 0.918 & 0.035 & 1.000 & & & \\
\hline & $(0.011)$ & (0.573) & (0.674) & $(0.494)$ & $(0.000)$ & $(0.722)$ & & & & \\
\hline OQ & $\begin{array}{l}-0.107 \\
(0.277)\end{array}$ & $\begin{array}{c}-0.038 \\
(0.701)\end{array}$ & $\begin{array}{c}0.072 \\
(0.466)\end{array}$ & $\begin{array}{c}0.015 \\
(0.881)\end{array}$ & $\begin{array}{c}0.913 \\
(0.000)\end{array}$ & $\begin{array}{l}-0.067 \\
(0.500)\end{array}$ & $\begin{array}{c}-0.846 \\
(0.000)\end{array}$ & 1.000 & & \\
\hline \multirow[t]{2}{*}{$\mathrm{CC} \times \mathrm{GF}$} & 0.024 & 0.123 & 0.089 & 0.016 & 0.322 & 0.865 & -0.299 & 0.2811 & 1.000 & \\
\hline & $(0.811)$ & $(0.210)$ & $(0.365)$ & $(0.871)$ & $(0.000)$ & $(0.000)$ & $(0.002)$ & $(0.0037)$ & & \\
\hline $\mathrm{CC} \times \mathrm{REC}$ & $\begin{array}{c}0.106 \\
(0.282)\end{array}$ & $\begin{array}{c}0.058 \\
(0.558)\end{array}$ & $\begin{array}{c}0.008 \\
(0.935)\end{array}$ & $\begin{array}{c}0.084 \\
(0.392)\end{array}$ & $\begin{array}{c}0.335 \\
(0.000)\end{array}$ & $\begin{array}{c}-0.028 \\
(0.774)\end{array}$ & $\begin{array}{c}0.063 \\
(0.527)\end{array}$ & $\begin{array}{l}0.3064 \\
(0.0015)\end{array}$ & $\begin{array}{l}0.0982 \\
(0.3190)\end{array}$ & 1.000 \\
\hline
\end{tabular}

Table 3 indicates the correlation coefficient values for combined estimations including moderation effects of green financing as well as the renewable energy consumption for this research investigation. The table shows that climate change negatively associated with bank stability with significant coefficient in case of ZROA, ZROE, SDROA and SDROE. It further shows that green financing and renewable energy consumption positively associated with bank stability measures stated above. Organizational quality is negatively associated with ZROA and ZROE while the same is positively associated with SDROA and SDROE. The first moderation effect of green financing, as well as the 2nd moderation effect of renewable energy consumption, is positively associated with bank stability measures. The probability values of correlation coefficients are indicated in parenthesis.

Table 4: Fixed Effect Estimates (Comparative)

\begin{tabular}{|c|c|c|c|c|c|c|c|c|c|c|c|c|}
\hline \multirow[b]{2}{*}{ Variables } & \multicolumn{4}{|c|}{ Malaysia } & \multicolumn{4}{|c|}{ Indonesia } & \multicolumn{4}{|c|}{ Thailand } \\
\hline & $\begin{array}{c}\text { Ln } \\
(\text { ZROA) }\end{array}$ & $\begin{array}{c}\text { Ln } \\
\text { (ZROE) }\end{array}$ & $\begin{array}{c}\text { Ln } \\
\text { (SDROA) }\end{array}$ & $\begin{array}{c}\text { Ln } \\
\text { (SDROE) }\end{array}$ & $\begin{array}{c}\text { Ln } \\
(\text { ZROA) }\end{array}$ & $\begin{array}{c}\text { Ln } \\
\text { (ZROE) }\end{array}$ & $\begin{array}{c}\text { Ln } \\
\text { (SDROA) }\end{array}$ & $\begin{array}{c}\text { Ln } \\
\text { (SDROE) }\end{array}$ & $\begin{array}{c}\text { Ln } \\
\text { (ZROA) }\end{array}$ & $\begin{array}{c}\text { Ln } \\
\text { (ZROE) }\end{array}$ & $\begin{array}{c}\text { Ln } \\
\text { (SDROA) }\end{array}$ & $\begin{array}{c}\text { Ln } \\
\text { (SDROE) }\end{array}$ \\
\hline $\mathrm{CC}$ & $\begin{array}{c}-8.61 * * * \\
(2.75)\end{array}$ & $\begin{array}{c}-46.4 * * * \\
(13.16)\end{array}$ & $\begin{array}{c}-1.6947 \\
(2.18)\end{array}$ & $\begin{array}{c}-72.46^{* *} \\
(32.50)\end{array}$ & $\begin{array}{l}-581.6 * * \\
(188.79)\end{array}$ & $\begin{array}{l}-372.02 \\
(642.87)\end{array}$ & $\begin{array}{c}-1504.1 * * \\
(754.91)\end{array}$ & $\begin{array}{c}-715.3 * * \\
(271.9)\end{array}$ & $\begin{array}{l}-297.4^{* * *} \\
(110.34)\end{array}$ & $\begin{array}{l}-499.8^{*} \\
(243.64)\end{array}$ & $\begin{array}{l}-57.98 \\
(209.7)\end{array}$ & $\begin{array}{l}-297.44 * \\
(150.34)\end{array}$ \\
\hline GF & $\begin{array}{l}.1549^{*} \\
(.0713)\end{array}$ & $\begin{array}{c}2.45^{*} \\
(1.192)\end{array}$ & $\begin{array}{l}72.33 * * \\
(26.22)\end{array}$ & $\begin{array}{l}10.5^{*} \\
(5.27)\end{array}$ & $\begin{array}{l}.957^{* *} \\
(.363)\end{array}$ & $\begin{array}{l}.0114 \\
(.9155)\end{array}$ & $\begin{array}{l}2.014^{*} \\
(1.011)\end{array}$ & $\begin{array}{c}.0124 \\
(1.8115)\end{array}$ & $\begin{array}{l}.0588 \\
(.9383)\end{array}$ & $\begin{array}{l}1.845 \\
(.8484)\end{array}$ & $\begin{array}{c}6.6702 \\
(3.5034)\end{array}$ & $\begin{array}{c}3.944 \\
(3.838)\end{array}$ \\
\hline RE & $\begin{array}{l}3.23^{*} \\
(1.97)\end{array}$ & $\begin{array}{l}71.93 * \\
(31.41)\end{array}$ & $\begin{array}{c}49.69 \\
(111.97)\end{array}$ & $\begin{array}{l}113.60 \\
(64.20)\end{array}$ & $\begin{array}{l}101.1^{* *} \\
(28.41)\end{array}$ & $\begin{array}{c}64.83 * * \\
(16.99)\end{array}$ & $\begin{array}{c}251.02 * * \\
(117.15)\end{array}$ & $\begin{array}{c}122.81 * * \\
(51.7)\end{array}$ & $\begin{array}{l}3.944 * * \\
(1.769)\end{array}$ & $\begin{array}{l}2.178^{*} \\
(1.031)\end{array}$ & $\begin{array}{l}21.10^{*} \\
(9.22)\end{array}$ & $\begin{array}{c}136.55^{*} \\
(68.47)\end{array}$ \\
\hline OQ & $\begin{array}{l}.91^{* *} \\
(.458)\end{array}$ & $\begin{array}{l}.566 * * \\
(.361)\end{array}$ & $\begin{array}{l}.5320 \\
(.599)\end{array}$ & $\begin{array}{l}2.14 * * * \\
(.7557)\end{array}$ & $\begin{array}{l}.2832^{*} \\
(.1376)\end{array}$ & $\begin{array}{l}.2773^{*} \\
(.1218)\end{array}$ & $\begin{array}{l}.8427 \\
(.5123)\end{array}$ & $\begin{array}{l}.1415^{*} \\
(.0388)\end{array}$ & $\begin{array}{l}-136.56 \\
(193.12)\end{array}$ & $\begin{array}{l}-233.80^{*} \\
(115.79)\end{array}$ & $\begin{array}{c}-3.394 * * \\
(.8924)\end{array}$ & $\begin{array}{c}-.0588 \\
(1.110)\end{array}$ \\
\hline $\mathbf{C C} \times \mathbf{G F}$ & $\begin{array}{l}.0537 * * \\
(.0188)\end{array}$ & $\begin{array}{c}1.250^{* * *} \\
(.491)\end{array}$ & $\begin{array}{c}35.24 * * \\
(12.69)\end{array}$ & $\begin{array}{c}5.114 * * \\
(2.07)\end{array}$ & $\begin{array}{l}1.081 \\
(1.442)\end{array}$ & $\begin{array}{c}.3684 \\
(1.2419)\end{array}$ & $\begin{array}{l}2.251^{*} \\
(1.129)\end{array}$ & $\begin{array}{l}.1724 * * \\
(.0457)\end{array}$ & $\begin{array}{c}2.6604 \\
(3.2823)\end{array}$ & $\begin{array}{c}1.543 \\
(5.623)\end{array}$ & $\begin{array}{l}4.8221 \\
(2.366)\end{array}$ & $\begin{array}{l}-2.660 \\
(2.76)\end{array}$ \\
\hline $\mathrm{CC} \times \mathbf{R E}$ & $\begin{array}{l}.0194 \\
(.356)\end{array}$ & $\begin{array}{l}35.21 * \\
(15.25)\end{array}$ & $\begin{array}{c}21.08 \\
(54.28)\end{array}$ & $\begin{array}{c}-53.22 \\
(30.60)\end{array}$ & $\begin{array}{c}159.99 * * \\
(51.53)\end{array}$ & $\begin{array}{c}101.86^{* *} \\
(46.52)\end{array}$ & $\begin{array}{c}413.57 \\
(407.73)\end{array}$ & $\begin{array}{c}196.32 \\
(349.25)\end{array}$ & $\begin{array}{c}-94.72 * * \\
(31.21)\end{array}$ & $\begin{array}{l}-156.04 \\
(76.43)\end{array}$ & $\begin{array}{c}11.924 \\
(274.72)\end{array}$ & $\begin{array}{c}-94.71 * * \\
(47.1)\end{array}$ \\
\hline Constant & $\begin{array}{c}12.90^{* *} \\
(5.06)\end{array}$ & $\begin{array}{l}96.31 * * \\
(39.37)\end{array}$ & $\begin{array}{c}5.57 * * * \\
(1.49)\end{array}$ & $\begin{array}{c}157.73^{* *} \\
(69.10)\end{array}$ & $\begin{array}{c}368.21 * * \\
(104.19)\end{array}$ & $\begin{array}{c}235.19^{* *} \\
(89.57)\end{array}$ & $\begin{array}{c}913.19^{* *} \\
(399.85)\end{array}$ & $\begin{array}{c}448.49^{* *} \\
(220.79)\end{array}$ & $\begin{array}{l}427.70^{* * *} \\
(204.03)\end{array}$ & $\begin{array}{c}747.03 * * \\
(368.9)\end{array}$ & $\begin{array}{c}94.50^{* * *} \\
(40.5)\end{array}$ & $\begin{array}{r}427.70 * * \\
(166.08)\end{array}$ \\
\hline $\mathbf{R}^{2}$ - Between & 0.094 & 0.2144 & 0.0156 & 0.6310 & 0.2815 & 0.0204 & 0.0764 & 0.5898 & 0.2218 & 0.2149 & 0.1035 & 0.2218 \\
\hline $\mathbf{R}^{2}$ - Within & 0.178 & 0.2943 & 0.3386 & 0.3484 & 0.1048 & 0.2172 & 0.2987 & 0.0418 & 0.0700 & 0.2592 & 0.2195 & 0.0700 \\
\hline $\mathbf{R}^{2}$ - Overall & 0.175 & 0.2678 & 0.2287 & 0.3273 & 0.1090 & 0.1988 & 0.2578 & 0.0376 & 0.0047 & 0.2168 & 0.2038 & 0.0047 \\
\hline Prob $>F$ & 0.049 & 0.037 & 0.033 & 0.008 & 0.006 & 0.0035 & 0.0034 & 0.0012 & 0.0303 & 0.0213 & 0.0371 & 0.0303 \\
\hline
\end{tabular}

ISSN 1869-0459 (print)/ISSN 1869-2885 (online)

(C) 2020 International Research Association for Talent Development and Excellence

http://www.iratde.com 


\begin{tabular}{|c|c|c|c|c|c|c|c|c|c|c|c|c|}
\hline Banks & 05 & 05 & 05 & 05 & 05 & 05 & 05 & 05 & 05 & 05 & 05 & 05 \\
\hline Years & 07 & 07 & 07 & 07 & 07 & 07 & 07 & 07 & 07 & 07 & 07 & 07 \\
\hline Observations & 35 & 35 & 35 & 35 & 35 & 35 & 35 & 35 & 35 & 35 & 35 & 35 \\
\hline $\begin{array}{l}\text { Hausman Test } \\
\text { (Prob>Chi2) }\end{array}$ & 0.0753 & 0.0779 & 0.0856 & 0.0729 & 0.0999 & 0.0865 & 0.0923 & 0.0977 & 0.0856 & 0.0722 & 0.0999 & 0.0897 \\
\hline
\end{tabular}

Table 4 indicates the fixed effect regression estimations of the present research investigations. It indicates that climate change is negatively influencing the bank stability with the significant coefficient of Malaysia, Indonesia and Thailand with different coefficient values stated. The green financing is positively impacting in all the three countries with significant coefficients in the case of Malaysia and Indonesia but not significant in the case of Thailand. Renewable energy consumption is positively and significantly affecting bank stability in all three countries. Organizational quality is significantly positive in the case of Malaysia and Indonesia but the same is negatively significant in case of Thailand. The negative coefficient of organizational quality in relation to bank stability is consistent with the negative finding of the same by (Shahid \& Abbas, 2012). The first moderation effect using green financing is significant with positive coefficient in the case of Malaysia only while the same is positively insignificant in the case of Indonesia and Thailand. The second moderation effect using renewable energy consumption is positively affecting in the case of Malaysia and Indonesia with very low significance while the same is negative and insignificant in the case of Thailand. The Hausman test value shows that fixed effect estimation is not appropriate in this study.

Table 5: Random Effect Estimates (Comparative)

\begin{tabular}{|c|c|c|c|c|c|c|c|c|c|c|c|c|}
\hline \multirow[b]{2}{*}{ Variables } & \multicolumn{4}{|c|}{ Malaysia } & \multicolumn{4}{|c|}{ Indonesia } & \multicolumn{4}{|c|}{ Thailand } \\
\hline & $\begin{array}{c}\text { Ln } \\
\text { (ZROA) }\end{array}$ & $\begin{array}{c}\text { Ln } \\
\text { (ZROE) }\end{array}$ & $\begin{array}{c}\text { Ln } \\
\text { (SDROA) }\end{array}$ & $\begin{array}{c}\text { Ln } \\
\text { (SDROE) }\end{array}$ & $\begin{array}{c}\text { Ln } \\
\text { (ZROA) }\end{array}$ & $\begin{array}{c}\text { Ln } \\
\text { (ZROE) }\end{array}$ & $\begin{array}{c}\text { Ln } \\
\text { (SDROA) }\end{array}$ & $\begin{array}{c}\text { Ln } \\
\text { (SDROE) }\end{array}$ & $\begin{array}{c}\text { Ln } \\
(\text { ZROA) }\end{array}$ & $\begin{array}{c}\text { Ln } \\
\text { (ZROE) }\end{array}$ & $\begin{array}{c}\text { Ln } \\
\text { (SDROA) }\end{array}$ & $\begin{array}{c}\text { Ln } \\
\text { (SDROE) }\end{array}$ \\
\hline $\mathrm{CC}$ & $\begin{array}{c}-8.62 * * \\
(4.48)\end{array}$ & $\begin{array}{c}-46.24 * * \\
(21.90)\end{array}$ & $\begin{array}{c}-0.236^{* *} \\
(.0495)\end{array}$ & $\begin{array}{c}-67.90^{* *} \\
(20.14)\end{array}$ & $\begin{array}{c}-573.43 * * * \\
(176.36)\end{array}$ & $\begin{array}{c}-362.6^{* *} \\
(125.83)\end{array}$ & $\begin{array}{c}-1473.8^{* * *} \\
(547.52)\end{array}$ & $\begin{array}{l}-672.4 * * \\
(230.24)\end{array}$ & $\begin{array}{l}-282.7^{*} \\
(138.23)\end{array}$ & $\begin{array}{c}-501.8 * * \\
(244.85)\end{array}$ & $\begin{array}{c}-65.02^{* *} \\
(25.20)\end{array}$ & $\begin{array}{c}-282.7^{* *} \\
(138.23)\end{array}$ \\
\hline GF & $\begin{array}{l}.1569 * * \\
(.0561)\end{array}$ & $\begin{array}{l}.1283^{* *} \\
(.0609)\end{array}$ & $\begin{array}{l}63.95 * * \\
(29.96)\end{array}$ & $\begin{array}{c}20.0^{* * *} \\
(9.35)\end{array}$ & $\begin{array}{l}1.0132 \\
(.9104)\end{array}$ & $\begin{array}{l}.0816 \\
(.8175)\end{array}$ & $\begin{array}{c}1.4771 \\
(1.2305)\end{array}$ & $\begin{array}{c}.3232 \\
(1.076)\end{array}$ & $\begin{array}{l}.2929 * * \\
(.0751)\end{array}$ & $\begin{array}{c}2.009 * * \\
(.8074)\end{array}$ & $\begin{array}{l}8.539 * \\
(4.312)\end{array}$ & $\begin{array}{l}.3064 * \\
(.156)\end{array}$ \\
\hline RE & $\begin{array}{l}3.24^{*} \\
(1.86)\end{array}$ & $\begin{array}{l}70.65^{* *} \\
(29.99)\end{array}$ & $\begin{array}{c}17.61 \\
(119.88)\end{array}$ & $\begin{array}{l}102.95^{*} \\
(60.18)\end{array}$ & $\begin{array}{c}99.63 * * * \\
(25.80)\end{array}$ & $\begin{array}{c}63.01 * * \\
(24.09)\end{array}$ & $\begin{array}{c}245.71 * * \\
(107.24)\end{array}$ & $\begin{array}{l}114.7^{*} \\
(57.99)\end{array}$ & $\begin{array}{l}.3064^{*} \\
(.136)\end{array}$ & $\begin{array}{l}.1760^{*} \\
(.0734)\end{array}$ & $\begin{array}{c}23.906 \\
(403.02)\end{array}$ & $\begin{array}{c}130.61 \\
(206.26)\end{array}$ \\
\hline OQ & $\begin{array}{l}.910 * * \\
(.432)\end{array}$ & $\begin{array}{l}.556 \\
(.465)\end{array}$ & $\begin{array}{l}.461 \\
(.644)\end{array}$ & $\begin{array}{l}2.10 * * * \\
(.7545)\end{array}$ & $\begin{array}{l}-.2830 \\
(.2362)\end{array}$ & $\begin{array}{l}-.2805 \\
(.2164)\end{array}$ & $\begin{array}{c}-.8349 * * \\
(.4303)\end{array}$ & $\begin{array}{l}-.1371 \\
(.5314)\end{array}$ & $\begin{array}{l}-130.6^{*} \\
(66.25)\end{array}$ & $\begin{array}{l}-235.3 * * \\
(116.68)\end{array}$ & $\begin{array}{l}-3.216 * * \\
(1.1240)\end{array}$ & $\begin{array}{l}-.2929 \\
(.9751)\end{array}$ \\
\hline $\mathbf{C C} \times \mathbf{G F}$ & $\begin{array}{l}.056^{* *} \\
(.021)\end{array}$ & $\begin{array}{l}.1024 * * \\
(.0495)\end{array}$ & $\begin{array}{c}31.25 * * \\
(14.54)\end{array}$ & $\begin{array}{l}9.773 * * \\
(3.528)\end{array}$ & $\begin{array}{l}1.2045 \\
(1.259)\end{array}$ & $\begin{array}{c}.4353 \\
(1.130)\end{array}$ & $\begin{array}{c}1.274 \\
(2.153)\end{array}$ & $\begin{array}{c}.5114 \\
(1.4824)\end{array}$ & $\begin{array}{l}.211 * * \\
(.089)\end{array}$ & $\begin{array}{c}.0713 \\
(4.023)\end{array}$ & $\begin{array}{l}6.081 * * \\
(2.847)\end{array}$ & $\begin{array}{l}.2106 \\
(2.980)\end{array}$ \\
\hline $\mathbf{C C} \times \mathbf{R E}$ & $\begin{array}{c}.0203^{* *} \\
(.007)\end{array}$ & $\begin{array}{c}34.66^{* * *} \\
(14.51)\end{array}$ & $\begin{array}{c}5.63 \\
(58.34)\end{array}$ & $\begin{array}{l}-48.32^{*} \\
(28.66)\end{array}$ & $\begin{array}{c}157.8^{* * *} * \\
(48.19)\end{array}$ & $\begin{array}{c}99.26 * * \\
(41.84)\end{array}$ & $\begin{array}{c}405.43^{*} \\
(204.6)\end{array}$ & $\begin{array}{l}184.48^{*} \\
(90.21)\end{array}$ & $\begin{array}{c}89.843 \\
(140.13)\end{array}$ & $\begin{array}{c}156.7^{* *} \\
(76.66)\end{array}$ & $\begin{array}{c}14.253 \\
(274.59)\end{array}$ & $\begin{array}{c}89.84 \\
(140.12)\end{array}$ \\
\hline Constant & $\begin{array}{c}12.90 \text { ** } \\
(6.65)\end{array}$ & $\begin{array}{c}95.72^{* *} \\
(44.47)\end{array}$ & $\begin{array}{c}36.59 * * \\
(16.10)\end{array}$ & $\begin{array}{c}147.47^{* *} \\
(64.08)\end{array}$ & $\begin{array}{c}362.73^{* * *} \\
(94.49)\end{array}$ & $\begin{array}{c}228.6^{* * *} \\
(78.98)\end{array}$ & $\begin{array}{c}893.54 * * \\
(437.22)\end{array}$ & $\begin{array}{c}419.1 * * * \\
(139.01)\end{array}$ & $\begin{array}{l}409.8^{* *} \\
(145.11)\end{array}$ & $\begin{array}{l}751.5^{* *} \\
(372.36)\end{array}$ & $\begin{array}{c}102.95^{* *} \\
(49.48)\end{array}$ & $\begin{array}{c}409.80^{* * *} \\
(145.11)\end{array}$ \\
\hline $\mathbf{R}^{2}$ - Between & 0.094 & 0.0132 & 0.0046 & 0.6784 & 0.3461 & 0.0212 & 0.1746 & 0.1170 & 0.1842 & 0.0310 & 0.1411 & 0.1842 \\
\hline $\mathbf{R}^{2}$ - Within & 0.178 & 0.2927 & 0.3314 & 0.3403 & 0.1037 & 0.2167 & 0.2912 & 0.0397 & 0.0400 & 0.2523 & 0.2179 & 0.0400 \\
\hline $\mathbf{R}^{2}$ - Overall & 0.175 & 0.2694 & 0.2362 & 0.3361 & 0.1101 & 0.1993 & 0.2646 & 0.0400 & 0.0246 & 0.2267 & 0.2076 & 0.0246 \\
\hline Prob $>$ chi 2 & 0.045 & 0.037 & 0.033 & 0.0277 & 0.049 & 0.0037 & 0.0016 & 0.0 .041 & 0.0161 & 0.0032 & 0.0027 & 0.0016 \\
\hline Banks & 05 & 05 & 05 & 05 & 05 & 05 & 05 & 05 & 05 & 05 & 05 & 05 \\
\hline Years & 07 & 07 & 07 & 07 & 07 & 07 & 07 & 07 & 07 & 07 & 07 & 07 \\
\hline Observations & 35 & 35 & 35 & 35 & 35 & 35 & 35 & 35 & 35 & 35 & 35 & 35 \\
\hline
\end{tabular}

ISSN 1869-0459 (print)/ISSN 1869-2885 (online)

(C) 2020 International Research Association for Talent Development and Excellence http://www.iratde.com 


\begin{tabular}{|c|c|c|c|c|c|c|c|c|c|c|c|}
\hline $\begin{array}{l}\text { LM Test } \\
(\text { (Prob>Chibar2) }\end{array}$ & 0.0573 & 0.0579 & 0.0586 & 0.0572 & 0.0599 & 0.0568 & 0.0529 & 0.0597 & 0.0568 & 0.0527 & 0.0559 \\
\hline
\end{tabular}

Table 5 indicates the comparative estimates using random-effect model for Malaysia, Indonesia and Thailand. The table reported negatively significant coefficient value of climate change in all the three countries which indicates that climate change decreases bank stability in the ASEAN region. The green financing, on the other hand, is positively affecting the bank stability in all the three countries with significant coefficient in the case of Malaysia and Thailand only. The renewable energy positively affects bank stability with low significance in case of all the three selected nations. Organization quality is positively affecting in case of Malaysia while the same is negatively affecting in the case of Indonesia and Thailand with low significance. The negative coefficient of organizational quality in relation to bank stability is consistent with the negative finding of the same by (Shahid \& Abbas, 2012). The first moderation using green financing is positively affecting bank stability in all the three countries with significance relation in the case of Malaysia and Thailand. The $2^{\text {nd }}$ moderation using renewable energy was significantly positive in the case of Malaysia and Indonesia while low significance in the case of Thailand. The LM test indicates that random effect model was also not supported for estimation of the current empirical research study. So the final choice of estimation for this empirical research lies in the use of pooled analysis.

Table 6: Pooled Estimates (Comparative)

\begin{tabular}{|c|c|c|c|c|c|c|c|c|c|c|c|c|}
\hline \multirow[b]{2}{*}{ Variables } & \multicolumn{4}{|c|}{ Malaysia } & \multicolumn{4}{|c|}{ Indonesia } & \multicolumn{4}{|c|}{ Thailand } \\
\hline & $\begin{array}{c}\text { Ln } \\
(\text { ZROA) }\end{array}$ & $\begin{array}{c}\text { Ln } \\
(\text { ZROE) }\end{array}$ & $\begin{array}{c}\text { Ln } \\
\text { (SDROA) }\end{array}$ & $\begin{array}{c}\text { Ln } \\
\text { (SDROE) }\end{array}$ & $\begin{array}{c}\text { Ln } \\
\text { (ZROA) }\end{array}$ & $\begin{array}{c}\text { Ln } \\
(\text { ZROE) }\end{array}$ & $\begin{array}{c}\text { Ln } \\
\text { (SDROA) }\end{array}$ & $\begin{array}{c}\text { Ln } \\
\text { (SDROE) }\end{array}$ & $\begin{array}{c}\text { Ln } \\
(\text { ZROA) }\end{array}$ & $\begin{array}{c}\text { Ln } \\
\text { (ZROE) }\end{array}$ & $\begin{array}{c}\text { Ln } \\
\text { (SDROA) }\end{array}$ & $\begin{array}{c}\text { Ln } \\
\text { (SDROE) }\end{array}$ \\
\hline $\mathrm{CC}$ & $\begin{array}{c}-8.620^{* * *} \\
(4.48)\end{array}$ & $\begin{array}{c}-46.23^{* *} \\
(23.11)\end{array}$ & $\begin{array}{c}-27.04 * * * \\
(8.02)\end{array}$ & $\begin{array}{c}-67.90^{* *} \\
(25.96)\end{array}$ & $\begin{array}{c}-573.44 * * \\
(240.06)\end{array}$ & $\begin{array}{c}-362.60^{* *} \\
(125.83)\end{array}$ & $\begin{array}{c}-1473.8 * * \\
(656.92)\end{array}$ & $\begin{array}{c}-672.37^{* *} \\
(180.95)\end{array}$ & $\begin{array}{c}-277.36^{* *} \\
(87.99)\end{array}$ & $\begin{array}{l}-501.8^{* * *} \\
(228.33)\end{array}$ & $\begin{array}{c}-67.46^{* *} \\
(24.79)\end{array}$ & $\begin{array}{c}-277.4 * * \\
(87.99)\end{array}$ \\
\hline GF & $\begin{array}{l}.1569 * * \\
(.0561)\end{array}$ & $\begin{array}{l}.1283 * * \\
(.0609)\end{array}$ & $\begin{array}{c}62.10^{* *} \\
(22.92)\end{array}$ & $\begin{array}{l}20.0^{* * *} \\
(9.35)\end{array}$ & $\begin{array}{l}1.0132 \\
(.8987)\end{array}$ & $\begin{array}{c}.0816 \\
(.8175)\end{array}$ & $\begin{array}{c}1.4770 \\
(1.7601)\end{array}$ & $\begin{array}{c}.32327 \\
(1.5425)\end{array}$ & $\begin{array}{l}.3928 * * \\
(.1676)\end{array}$ & $\begin{array}{c}.1759^{* *} \\
(.073)\end{array}$ & $\begin{array}{l}9.016^{*} \\
(4.581)\end{array}$ & $\begin{array}{l}.6411^{*} \\
(0.284)\end{array}$ \\
\hline RE & $\begin{array}{l}3.24 * \\
(1.86)\end{array}$ & $\begin{array}{l}70.65^{*} \\
(27.24)\end{array}$ & $\begin{array}{c}9.74 \\
(144.55)\end{array}$ & $\begin{array}{c}102.95^{* *} \\
(50.35)\end{array}$ & $\begin{array}{c}99.64 * * \\
(45.67)\end{array}$ & $\begin{array}{l}63.01 * * \\
(24.09)\end{array}$ & $\begin{array}{c}245.71 * * \\
(116.33)\end{array}$ & $\begin{array}{c}114.69^{* *} \\
(56.41)\end{array}$ & $\begin{array}{l}.6411^{* *} \\
(.2801)\end{array}$ & $\begin{array}{l}235.22^{* * *} \\
(101.60)\end{array}$ & $\begin{array}{c}24.92 \\
(329.23)\end{array}$ & $\begin{array}{c}128.37 \\
(181.63)\end{array}$ \\
\hline OQ & $\begin{array}{l}.905 * * \\
.432)\end{array}$ & $\begin{array}{c}.556 \\
(.341)\end{array}$ & $\begin{array}{l}.4438 \\
(.5772)\end{array}$ & $\begin{array}{l}2.097 * * \\
(.7545)\end{array}$ & $\begin{array}{l}-.2831 \\
(.2090)\end{array}$ & $\begin{array}{l}-.2805 \\
(.2164)\end{array}$ & $\begin{array}{l}-.8349^{*} \\
(.4867)\end{array}$ & $\begin{array}{l}-.1371 \\
(.40842)\end{array}$ & $\begin{array}{c}-128.37^{*} \\
(61.63)\end{array}$ & $\begin{array}{c}-2.008^{* * *} \\
(.9458)\end{array}$ & $\begin{array}{l}-3.167^{*} \\
(1.767)\end{array}$ & $\begin{array}{l}-.3929 \\
(.9677)\end{array}$ \\
\hline $\mathbf{C C} \times \mathbf{G F}$ & $\begin{array}{c}.0562 * * \\
(.021)\end{array}$ & $\begin{array}{l}.1025 * * \\
(.0435)\end{array}$ & $\begin{array}{l}30.37 * * \\
(11.16)\end{array}$ & $\begin{array}{l}9.77 * * \\
(4.53)\end{array}$ & $\begin{array}{c}1.2045 \\
(1.2317)\end{array}$ & $\begin{array}{c}.4353 \\
(1.1309)\end{array}$ & $\begin{array}{l}1.2743 \\
(2.709)\end{array}$ & $\begin{array}{c}.5115 \\
(2.134)\end{array}$ & $\begin{array}{l}.4235 * * \\
(.1456)\end{array}$ & $\begin{array}{c}.0713 \\
(2.755)\end{array}$ & $\begin{array}{l}6.402 * * \\
(2.214)\end{array}$ & $\begin{array}{l}.4235 \\
(3.456)\end{array}$ \\
\hline $\mathbf{C C} \times \mathbf{R E}$ & $\begin{array}{l}.0204^{*} \\
(.007)\end{array}$ & $\begin{array}{l}34.66^{*} \\
(16.84)\end{array}$ & $\begin{array}{l}1.8329 \\
(62.63)\end{array}$ & $\begin{array}{l}48.32^{*} \\
(23.96)\end{array}$ & $\begin{array}{c}157.77 * * \\
(75.73)\end{array}$ & $\begin{array}{l}99.26 * * \\
(41.84)\end{array}$ & $\begin{array}{c}405.43 * * \\
(202.38)\end{array}$ & $\begin{array}{c}184.49^{* *} \\
(62.26)\end{array}$ & $\begin{array}{c}88.08 \\
(123.88)\end{array}$ & $\begin{array}{c}156.66 \\
(136.96)\end{array}$ & $\begin{array}{c}15.06 \\
(222.50)\end{array}$ & $\begin{array}{c}88.078 \\
(123.88)\end{array}$ \\
\hline Constant & $\begin{array}{c}12.91 * * \\
(6.15)\end{array}$ & $\begin{array}{c}95.72 * * \\
(36.75)\end{array}$ & $\begin{array}{l}47.05 * * \\
(18.73)\end{array}$ & $\begin{array}{l}147.5^{* *} \\
(56.60)\end{array}$ & $\begin{array}{c}362.7 * * * \\
(84.84)\end{array}$ & $\begin{array}{c}228.6^{* * * *} \\
(38.97)\end{array}$ & $\begin{array}{c}893.5 * * * \\
(188.10)\end{array}$ & $\begin{array}{c}419.1 * * * \\
(75.13)\end{array}$ & $\begin{array}{c}403.04 * * * \\
(68.96)\end{array}$ & $\begin{array}{l}751.5 * * \\
(330.55)\end{array}$ & $\begin{array}{c}106.02 * * * \\
(28.2)\end{array}$ & $\begin{array}{c}403.04 * * * \\
(68.96)\end{array}$ \\
\hline $\mathbf{R}^{2}$ & 0.175 & 0.2694 & 0.2366 & 0.3361 & 0.1101 & 0.1993 & 0.2646 & 0.1400 & 0.1598 & 0.2267 & 0.2077 & 0.0273 \\
\hline $\mathbf{R}^{2}$ - Adj & 0.156 & 0.2129 & 0.1730 & 0.2939 & 0.0972 & 0.1777 & 0.2070 & 0.1239 & 0.1265 & 0.1610 & 0.1380 & 0.0181 \\
\hline Prob $>$ F & 0.0018 & 0.0113 & 0.0070 & 0.0096 & 0.0035 & 0.0044 & 0.0498 & 0.0047 & 0.0273 & 0.031 & 0.0032 & 0.0013 \\
\hline Banks & 05 & 05 & 05 & 05 & 05 & 05 & 05 & 05 & 05 & 05 & 05 & 05 \\
\hline Years & 07 & 07 & 07 & 07 & 07 & 07 & 07 & 07 & 07 & 07 & 07 & 07 \\
\hline Observations & 35 & 35 & 35 & 35 & 35 & 35 & 35 & 35 & 35 & 35 & 35 & 35 \\
\hline
\end{tabular}

Table 6 reported the pooled regression analysis using the OLS technique of estimation for the present empirical research study for the Malaysia, Indonesia and Thailand. It indicates that Climate change significantly decreases the bank stability in all the selected three countries of the ASEAN region. The green financing,

ISSN 1869-0459 (print)/ISSN 1869-2885 (online)

(C) 2020 International Research Association for Talent Development and Excellence http://www.iratde.com 
on the other hand, increases bank stability with significant coefficient in the case of Malaysia and Thailand while the same is insignificant in the case of Indonesia. Renewable energy is positively significant in all the three countries. Organizational quality is positively significant in the case of Malaysia while the same is negatively insignificant in the case of Indonesia and negatively significant in case of Thailand. The negative coefficient of organizational quality in relation to bank stability is consistent with the negative finding of the same by (Shahid \& Abbas, 2012). The first moderation effect of green financing is positively significant in case Malaysia and Thailand while the same is positively insignificant in the case of Indonesia. The second moderation effect of renewable energy is significantly positive in the case of Malaysia and Indonesia while the same is positively insignificant in the case of Thailand. The Pooled OLS model is statistically significant for all the three selected countries of ASEAN region with the r-square value as 18\% approximately in case of Malaysia, $11 \%$ in case of Indonesia and $16 \%$ in case of Thailand. The reason for the lowest r-square for this empirical study is that the bank related internal factors were not included in the model that may enhance the r-square for this study.

Table 7: Panel data analysis (Combine Estimates)

\begin{tabular}{|c|c|c|c|c|c|c|c|c|c|c|c|c|}
\hline \multirow[b]{2}{*}{ Variables } & \multicolumn{4}{|c|}{ Fixed Effect } & \multicolumn{4}{|c|}{ Random Effect } & \multicolumn{4}{|c|}{ Pooled OLS } \\
\hline & $\begin{array}{c}\text { Ln } \\
\text { (ZROA) }\end{array}$ & $\begin{array}{c}\text { Ln } \\
\text { (ZROE) }\end{array}$ & $\begin{array}{c}\text { Ln } \\
\text { (SDROA) }\end{array}$ & $\begin{array}{c}\text { Ln } \\
\text { (SDROE) }\end{array}$ & $\begin{array}{c}\text { Ln } \\
\text { (ZROA) }\end{array}$ & $\begin{array}{c}\text { Ln } \\
\text { (ZROE) }\end{array}$ & $\begin{array}{c}\text { Ln } \\
\text { (SDROA) }\end{array}$ & $\begin{array}{c}\text { Ln } \\
\text { (SDROE) }\end{array}$ & $\begin{array}{c}\text { Ln } \\
\text { (ZROA) }\end{array}$ & $\begin{array}{c}\text { Ln } \\
\text { (ZROE) }\end{array}$ & $\begin{array}{c}\text { Ln } \\
\text { (SDROA) }\end{array}$ & $\begin{array}{c}\text { Ln } \\
\text { (SDROE) }\end{array}$ \\
\hline $\mathrm{CC}$ & $\begin{array}{l}-6.81 * * \\
(3.384)\end{array}$ & $\begin{array}{l}-3.79 * * \\
(1.584)\end{array}$ & $\begin{array}{c}-20.73 * * \\
(9.81)\end{array}$ & $\begin{array}{c}-1.876^{* *} \\
(0.72)\end{array}$ & $\begin{array}{l}-6.81 * * \\
(3.168)\end{array}$ & $\begin{array}{c}-6.256^{* * *} \\
(1.909)\end{array}$ & $\begin{array}{l}1.69^{* *} \\
(0.818)\end{array}$ & $\begin{array}{c}-3.41 * * * \\
(1.06)\end{array}$ & $\begin{array}{c}-1.02^{* * * *} \\
(0.295)\end{array}$ & $\begin{array}{c}-6.26 * * * \\
(1.909)\end{array}$ & $\begin{array}{l}-1.69 * * \\
(0.818)\end{array}$ & $\begin{array}{c}-3.41^{* * *} \\
(1.06)\end{array}$ \\
\hline GF & $\begin{array}{l}.1986^{*} \\
(.085)\end{array}$ & $\begin{array}{l}.1620 \\
(.2751)\end{array}$ & $\begin{array}{l}.2653 \\
(.6349)\end{array}$ & $\begin{array}{l}-.1241 \\
(.4473)\end{array}$ & $\begin{array}{l}.1986^{*} \\
(.0836)\end{array}$ & $\begin{array}{l}.168^{*} \\
(.088)\end{array}$ & $\begin{array}{l}.652^{*} \\
(.326)\end{array}$ & $\begin{array}{l}.00437 \\
(.398)\end{array}$ & $\begin{array}{l}.148^{*} \\
(.071)\end{array}$ & $\begin{array}{l}.168^{*} \\
(.088)\end{array}$ & $\begin{array}{l}.652^{*} \\
(.326)\end{array}$ & $\begin{array}{l}.00437 \\
(.398)\end{array}$ \\
\hline RE & $\begin{array}{l}2.604 * \\
(1.277)\end{array}$ & $\begin{array}{l}2.4812 \\
(2.278)\end{array}$ & $\begin{array}{c}12.121^{* * *} \\
(5.257)\end{array}$ & $\begin{array}{c}3.197 \\
(3.703)\end{array}$ & $\begin{array}{c}2.603 \\
(2.348)\end{array}$ & $\begin{array}{c}3.691 * * * \\
(1.136)\end{array}$ & $\begin{array}{c}1.128 \\
(2.867)\end{array}$ & $\begin{array}{l}2.271^{*} \\
(1.024)\end{array}$ & $\begin{array}{c}.5414 \\
(1.187)\end{array}$ & $\begin{array}{c}3.691 * * * \\
(1.136)\end{array}$ & $\begin{array}{l}1.1275 \\
(2.867)\end{array}$ & $\begin{array}{l}2.271^{*} \\
(1.024)\end{array}$ \\
\hline OQ & $\begin{array}{l}-.0431 \\
(.1791)\end{array}$ & $\begin{array}{l}.1096 \\
(.1427)\end{array}$ & $\begin{array}{c}.2105 \\
(.3293)\end{array}$ & $\begin{array}{l}.2390 \\
(.2320)\end{array}$ & $\begin{array}{l}-.0432 \\
(.1471)\end{array}$ & $\begin{array}{l}-.1023 \\
(.1343)\end{array}$ & $\begin{array}{c}.3455 \\
(.3387)\end{array}$ & $\begin{array}{c}.3072 \\
(.2155)\end{array}$ & $\begin{array}{l}-.0336 \\
(.1402)\end{array}$ & $\begin{array}{l}-.1023 \\
(.1343)\end{array}$ & $\begin{array}{c}.3456 \\
(.3388)\end{array}$ & $\begin{array}{l}-.3072 \\
(.2155)\end{array}$ \\
\hline $\mathbf{C C} \times \mathbf{G F}$ & $\begin{array}{c}.054 \\
(.1683)\end{array}$ & $\begin{array}{c}.0177 \\
(.1807)\end{array}$ & $\begin{array}{l}.0211 \\
(.4171)\end{array}$ & $\begin{array}{c}.1079 \\
.2939)\end{array}$ & $\begin{array}{l}-.054 * * \\
(.0186)\end{array}$ & $\begin{array}{l}.0249 * * \\
(.0111)\end{array}$ & $\begin{array}{l}.2750 * * \\
(.1167)\end{array}$ & $\begin{array}{c}.0342 \\
(.2650)\end{array}$ & $\begin{array}{l}.0501^{* *} \\
(.0252)\end{array}$ & $\begin{array}{l}.0249^{* *} \\
(.0111)\end{array}$ & $\begin{array}{l}.2752^{* * *} \\
(.1167)\end{array}$ & $\begin{array}{l}.0342 \\
(.2651)\end{array}$ \\
\hline $\mathrm{CC} \times \mathrm{RE}$ & $\begin{array}{l}1.990^{*} \\
(1.012)\end{array}$ & $\begin{array}{l}.7572^{*} \\
(0.383)\end{array}$ & $\begin{array}{l}6.601^{*} \\
(3.884)\end{array}$ & $\begin{array}{l}.6388^{*} \\
(0.236)\end{array}$ & $\begin{array}{l}1.99^{*} \\
(.735)\end{array}$ & $\begin{array}{c}1.519 * * * \\
(.4820)\end{array}$ & $\begin{array}{c}.4815 \\
(1.216)\end{array}$ & $\begin{array}{l}.8718^{* * *} \\
(.3738)\end{array}$ & $\begin{array}{l}.3146^{* *} \\
(.1076)\end{array}$ & $\begin{array}{c}1.520 * * * \\
(.4820)\end{array}$ & $\begin{array}{c}.4813 \\
(1.216)\end{array}$ & $\begin{array}{l}.8718^{* * *} \\
(.3737)\end{array}$ \\
\hline Constant & $\begin{array}{l}10.9^{* *} \\
(5.14)\end{array}$ & $\begin{array}{l}8.33 * * \\
(3.73)\end{array}$ & $\begin{array}{l}41.23 * * \\
(20.15)\end{array}$ & $\begin{array}{c}10.06^{* * *} \\
(4.20)\end{array}$ & $\begin{array}{c}10.93^{* * *} \\
(4.50)\end{array}$ & $\begin{array}{c}12.54 * * * \\
(4.161)\end{array}$ & $\begin{array}{l}5.01 * * \\
(2.51)\end{array}$ & $\begin{array}{c}8.86^{* *} \\
(3.68)\end{array}$ & $\begin{array}{l}2.85^{* *} \\
(1.35)\end{array}$ & $\begin{array}{c}12.54 * * * \\
(4.161)\end{array}$ & $\begin{array}{l}5.01 * * \\
(2.41)\end{array}$ & $\begin{array}{l}8.86^{* * *} \\
(3.68)\end{array}$ \\
\hline $\mathbf{R}^{2}$ - Between & 0.2231 & 0.0001 & 0.0308 & 0.0397 & 0.2058 & 0.0594 & 0.0540 & 0.1254 & - & - & - & - \\
\hline $\mathbf{R}^{2}$ - Within & 0.0325 & 0.1316 & 0.1211 & 0.0434 & 0.0221 & 0.0268 & 0.0240 & 0.0292 & - & - & - & - \\
\hline $\mathbf{R}^{2}$ - Overall & 0.0349 & 0.0371 & 0.0865 & 0.0251 & 0.2448 & 0.2205 & 0.2281 & 0.2362 & 0.2448 & 0.2205 & 0.2281 & 0.2362 \\
\hline Prob $>F$ & 0.0289 & 0.0492 & 0.0458 & 0.0227 & 0.0190 & 0.0368 & 0.8296 & 0.0195 & 0.0493 & 0.0458 & 0.0275 & 0.0193 \\
\hline Banks & 15 & 15 & 15 & 15 & 15 & 15 & 15 & 15 & 15 & 15 & 15 & 15 \\
\hline Years & 7 & 7 & 7 & 7 & 7 & 7 & 7 & 7 & 7 & 7 & 7 & 7 \\
\hline Observations & 105 & 105 & 105 & 105 & 105 & 105 & 105 & 105 & 105 & 105 & 105 & 105 \\
\hline $\begin{array}{l}\text { Hausman Test } \\
\text { (Prob>Chi2) }\end{array}$ & 0.9039 & 0.9974 & 0.1499 & 0.9641 & - & - & - & - & - & - & - & - \\
\hline $\begin{array}{l}\text { LM Test } \\
\text { (Prob>Chibar2) }\end{array}$ & - & - & - & - & 0.2954 & 1.0000 & 0.2965 & 1.0000 & - & - & - & - \\
\hline
\end{tabular}

ISSN 1869-0459 (print)/ISSN 1869-2885 (online) 
Table 7 indicates the combined panel estimates for all the three countries using Fixed effect, random effect and Pooled data analysis techniques. The table reported that Hausman specification test, as well as LM test, were not significant to confirm either models; fixed effect or random effect. Hence Pooled OLS technique again was finalized as an appropriate approach for estimating the purpose of the study. The r-squared values for OLS estimate ranges between $22 \%$ to $24 \%$ while for the fixed effect it ranges from $3 \%$ to $8 \%$ along with $22 \%$ to $24 \%$ in case of random effect modelling. All the three models were statistically significance. The final model estimations of OLS technique for combined panel data revealed that Climate change significantly decreases banks stability in the selected ASEAN countries. The green financing as an independent variable positively affects the bank stability in this region with low significance. Renewable energy consumption increases significantly the bank stability in this region. The combined estimates show a negative relation between organizational quality and bank's stability with insignificant coefficient for this region. The negative coefficient of organizational quality in relation to bank stability is consistent with the negative finding of the same by (Shahid \& Abbas, 2012). The first moderation effect using green financing shows that climate change coupled with green financing enhances the bank stability in the ASEAN region with significance values. The second moderation effect using renewable energy consumption shows that climate change coupled with renewable energy consumption enhances the bank stability in the ASEAN region with significance value.

\section{Conclusion and Recommendations}

The primary motive for this empirical research study was to determine the climate change impact on bank stability for Malaysia, Indonesia and Thailand in comparative panel as well as combined panel approach considering the role of green financing as well as renewable energy as the moderating factors. For this purpose, five banks were selected on the basis of green financing from each of the three selected countries. The bank stability as the dependent variable of the study was measured by four proxies; Z score of ROA, ROE and SD of ROA and ROE. The independent variable was climate change which was measured by $\mathrm{CO} 2$ emissions. The independent variables were green financing, renewable energy and organizational quality while the green financing and renewable energy consumption were also used as the moderating variables of this empirical research investigation. The data for this purpose was collected from the financial statement of the respective banks as well as from the WDI database along with WDI governance index databases from the year 2012-2018. For the purpose of comparative analysis of Malaysia, Indonesia and Thailand to drive the motive of present research investigation, a panel of five banks from each country was analyzed using fixed effect, random effect and pooled OLS estimation. The Hausman specification and LM tests were not significant at all which confirmed the OLS estimation as an appropriate technique for the analysis of comparative study as well as the combined panel study. The comparative findings indicate that bank stability strongly decreased by climate change in Malaysia, Indonesia and Thailand. The Green financing strongly enhances bank stability in the case of Malaysia and Thailand while renewable energy is a less important factor to enhance the bank stability for all the three countries. The moderation effect of green financing significantly enhances bank stability in the case of Malaysia and Thailand while the moderation effect of renewable energy enhances bank stability in the case of Malaysia and Indonesia only. The combined estimates conclude that climate changes strongly decreases the bank stability in the ASEAN region while the green financing and renewable energy positively influences the bank stability in this region with low significance. The moderation effect of green financing, as well as renewable energy positively, enhances the bank stability measures of ZROA and ZROE only in this region. The policy implication for this empirical investigation concludes that the policymakers in ASEAN region should promote green financing in all the banks with renewable energy in their economies as the source of alternative energy consumption to control to devastating changes in climate so that bank stability in this region is insured.

ISSN 1869-0459 (print)/ISSN 1869-2885 (online) (c) 2020 International Research Association for Talent Development and Excellence http://www.iratde.com 


\section{References:}

1. Ahamed, M. M., \& Mallick, S. K. (2019). Is financial inclusion good for bank stability? International evidence. Journal of Economic Behavior \& Organization, 157, 403-427.

2. Albaity, M., Mallek, R. S., \& Noman, A. H. M. (2019). Competition and bank stability in the MENA region: The moderating effect of Islamic versus conventional banks. Emerging Markets Review, 38, 310-325.

3. Ashraf, D., Rizwan, M. S., \& L'Huillier, B. (2016). A net stable funding ratio for Islamic banks and its impact on financial stability: An international investigation. Journal of Financial Stability, 25, 47-57.

4. Danişman, G. Ö. (2018). Determinants of Bank Stability: A Financial Statement Analysis of Turkish Banks 1. Sosyoekonomi, 26(38), 87-103.

5. De Jonghe, O. (2010). Back to the basics in banking? A micro-analysis of banking system stability. Journal of financial intermediation, 19(3), 387-417.

6. Diaconu, I.-R., \& Oanea, D.-C. (2015). Determinants of Bank's Stability. Evidence from CreditCoop. Procedia Economics and Finance, 32, 488-495.

7. Diaconu, R.-I., \& Oanea, D.-C. (2014). The main determinants of bank's stability. Evidence from Romanian banking sector. Procedia Economics and Finance, 16, 329-335.

8. Fang, Y., Hasan, I., \& Marton, K. (2014). Institutional development and bank stability: Evidence from transition countries. Journal of Banking \& Finance, 39, 160-176.

9. Gudmundsson, R., Ngoka-Kisinguh, K., \& Odongo, M. T. (2013). The role of capital requirements on bank competition and stability: The case of the Kenyan banking industry. Kenya Bankers Association-KBA Centre for Research on Financial Markets and Policy Working Paper Series.

10. Guy, K., \& Lowe, S. (2011). Non-performing loans and bank stability in Barbados. Economic Review, 37(1), 77-82.

11. Hsieh, M. F., Chen, P. F., Lee, C. C., \& Yang, S. J. (2013). How does diversification impact bank stability? The role of globalization, regulations, and governance environments. Asia-Pacific Journal of Financial Studies, 42(5), 813-844.

12. Ibrahim, M. H., \& Rizvi, S. A. R. (2017). Do we need bigger Islamic banks? An assessment of bank stability. Journal of Multinational Financial Management, 40, 77-91.

13. Jahn, N., \& Kick, T. (2012). Determinants of banking system stability: A macro-prudential analysis. Finance Center Münster, University of Münster.

14. Kamran, H. W., Mohamed-Arshad, S. B., \& Omran, A. (2019). Country governance, market concentration and financial market dynamics for banks stability in Pakistan. Research in World Economy, 10(2), 136-146.

15. Karim, N. A., Al-Habshi, S. M. S. J., \& Abduh, M. (2016). Macroeconomics indicators and bank stability: A case of banking in Indonesia. Buletin Ekonomi Moneter Dan Perbankan, 18(4), 431-448.

16. Koetter, M., \& Poghosyan, T. (2010). Real estate prices and bank stability. Journal of Banking \& Finance, 34(6), 1129-1138.

17. Mat Rahim, S. R., \& Zakaria, R. H. (2013). Comparison on stability between Islamic and conventional banks in Malaysia. Journal of Islamic Economics, Banking and Finance, 113(915), 1-19.

18. Moyo, J., Nandwa, B., Council, D. E., Oduor, J., \& Simpasa, A. (2014). Financial sector reforms, competition and banking system stability in Sub-Saharan Africa. New perspectives.

19. Ozili, P. K. (2018). Banking stability determinants in Africa. International Journal of Managerial Finance.

20. Rupeika-Apoga, R., Zaidi, H., Thalassinos, E., \& Thalassinos, I. (2018). Bank stability: The Case of Nordic and non-Nordic banks in Latvia. International Journal of Economics \& Business Administration, 6(2), 3955.

21. Shahid, M. A., \& Abbas, Z. (2012). Financial stability of Islamic banking in Pakistan: An empirical study. African Journal of Business Management, 6(10), 3706-3714.

ISSN 1869-0459 (print)/ISSN 1869-2885 (online) (c) 2020 International Research Association for Talent Development and Excellence http://www.iratde.com 
Talent Development \& Excellence

Vol.12, No.2s, 2020, 3738-3751

22. Sinha, P., \& Sharma, S. (2016). Determinants of bank profits and its persistence in Indian Banks: a study in a dynamic panel data framework. International Journal of System Assurance Engineering and Management, $7(1), 35-46$.

23. Soedarmono, W., Machrouh, F., \& Tarazi, A. (2011). Bank market power, economic growth and financial stability: Evidence from Asian banks. Journal of Asian Economics, 22(6), 460-470.

24. Tan, A. Y., \& Anchor, J. (2016). Stability and profitability in the Chinese banking industry: evidence from an auto-regressive-distributed linear specification. Investment Management and Financial Innovations, $13(4), 120-128$.

25. Umar, M., \& Sun, G. (2018). Determinants of non-performing loans in Chinese banks. Journal of Asia Business Studies.

26. Vallascas, F., \& Keasey, K. (2012). Bank resilience to systemic shocks and the stability of banking systems: Small is beautiful. Journal of International Money and Finance, 31(6), 1745-1776. 